\title{
Pengetahuan Wisatawan Mancanegara atas Kehadiran Patung Garuda Wisnu Kencana sebagai Ikon Pariwisata Indonesia
}

\author{
Supina \\ Universitas Bunda Mulia \\ supina@bundamulia.ac.id
}

\begin{abstract}
In 2018, Indonesia has a new tourism icon, namely Garuda Wisnu Kencana Statue, which located in Bali, the most famous tourist destination in Indonesia. The presence of this tourism icon is certainly expected to support increasing numbers of tourists to Bali and Indonesia, especially for foreign tourists. One year has passed but there still no tourism improvement from the presence of this tourism icon, there are no major activities that can invite tourists to visit and there is no research on this tourism icon. Therefore, descriptive research was conducted by distributing questionnaires through online media to foreign tourists from five continents in the world to find out whether foreign tourists knew about the presence of the Indonesian tourism icon Garuda Wisnu Kencana Statue. The results of this study show that $87.5 \%$ of respondents from 28 countries in various parts of the world did not know about the presence of this new tourism icon, and of course there was no significant impact resulting from the tourism icon. The low level of knowledge of the presence of tourism icons surely related to the marketing method both carried out by the local tourism government and the central tourism government. Discussion of marketing methods certainly requires further complete research but the results of questionnaires show that according to respondents one of the best marketing media to promote a new tourism icon are social media and the internet / website.
\end{abstract}

Keywords:tourism, icon, awareness

\begin{abstract}
Abstrak
Pada tahun 2018 Indonesia memiliki ikon pariwisata yaitu patung Garuda Wisnu Kencana yang terletak di Bali yang mana juga merupakan destinasi wisata paling terkenal di Indonesia, kehadiran ikon pariwisata ini tentunya diharapkan dapat menunjang peningkatkan jumlah wisatawan ke Bali dan Indonesia terutama untuk wisatawan mancanegara. Satu tahun berlalu tetapi masih belum terdengar hal yang baru yang dihasilkan dari kehadiran ikon pariwisata ini, belum ada kegiatan besar yang dapat mengundang wisatawan berkunjung serta belum adanya penelitian pada ikon pariwisata ini. Oleh karena itu, penelitian deskriptif dilakukan dengan menyebarkan kuesioner melalui media daring terhadap wisatawan mancanegara yang berasal dari lima benua di dunia untuk mengetahui apakah wisatawan mancanegara mengetahui tentang kehadiran ikon pariwisata Indonesia Patung Garuda Wisnu Kencana ini. Hasil dari penelitian ini menunjukkan sebanyak 87,5\% responden yang berasal dari 28 negara diberbagai belahan dunia tidak mengetahui mengetahui kehadiran ikon pariwisata baru ini, dan tentu saja tidak ada dampak berarti yang dihasilkan dari ikon pariwisata tersebut. Rendahnya tingkat pengetahuan akan kehadiran ikon pariwisata ini tentu saja berhubungan dengan metode pemasaran baik yang dilakukan pemerintah pariwisata lokal maupun pemerintah pariwisata pusat. Pembahasan mengenai metode pemasaran tentu saja membutuhkan penelitian lengkap lebih lanjut tetapi hasil dari penyebaran kuesioner menunjukkan bahwa menurut responden salah satu media pemasaran terbaik untuk mempromosikan ikon pariwisata baru adalah media sosial dan internet/website.
\end{abstract}

Kata kunci:pariwisata, ikon, kesadaran

\section{Pendahuluan}

Popularitas Bali tentu saja tidak perlu diragukan, pada tahun 2017 Bali terpilih sebagai Destinasi wisata terbaik di dunia versi Trip Advisor's Travellers Awards mengalahkan London pada peringkat kedua dan Paris pada peringkat pertama (Sri, 2017). Meski pada tahun 2018 Bali 
harus turun tiga peringkat dari peringkat pertama menjadi peringkat ke-empat dikalahkan oleh Paris pada peringkat pertama, London peringkat kedua, dan Roma pada peringkat ketiga.

Pada tahun 2016, kementerian Pariwisata Republik Indonesia menetapkan 10 destinasi wisata unggulan yaitu danau Toba (Sumatera Utara), Tanjung Kelayang (Bangka Belitung), Tanjung Lesung (Banten), Kepulauan Seribu (DKI Jakarta), Candi Borobudur (Jawa Tengah), Gunung Bromo (Jawa Timur), Mandalika (NTB), Pulau Komodo (Nusa Tenggara Timur), Taman Nasional Wakatobi (Sulawesi Tenggara), dan Morotai (Maluku Utara). Kesepuluh destinasi wisata unggulan ini dicanangkan untuk menjadi 10 Bali Baru. Hal ini menunjukkan Bali adalah destinasi wisata contoh untuk 10 destinasi wisata unggulan tersebut. Dalam mencontoh kesuksesan Bali, setiap destinasi wisata perlu memperhatikan portofolio perbandingan destinasi wisata dengan kompetitor, karena setiap destinasi wisata di Indonesia memiliki keunikannya masing-masing.

Bali sendiri mengungguli untuk tipe destinasi pantai. Sesuai dengan hasil penelitian yang dilaksanakan dinas pariwisata Bali akhir 2013 menyebutkan bahwa kelompok wisatawan nusantara yang menyatakan ketertarikannya pada keindahan alam dan keunikan seni budaya masing - masing adalah 37,5 persen dan 35,2 persen. Selebihnya adalah keramah-tamahan penduduk 9,1 persen, atraksi wisata yang beragam 7,6 persen, fasilitas pariwisata yang berkualitas 5,4 persen, biaya berlibur relatif murah 4,9 persen, dan sejumlah daya tarik lainnya 0,3 persen. Dari berbagai jenis daya tarik wisata alam yang ada di Bali, lebih dari separuh atau 54,1 persen wisnus yang mengunjungi Bali menyatakan lebih berminat pada pantai/laut, disusul pegunungan 18,2 persen dan persawahan 9,9 persen (Sutika, 2014).

Sebagai destinasi wisata yang telah sukses di Indonesia, Bali pun terpilih untuk menjadi lokasi peletakan ikon wisata Indonesia yaitu Patung Garuda Wisnu Kencana. Pada tahun 2018 tepatnya pada tanggal 22 September 2018, Patung Garuda Wisnu Kencana yang terletak di Garuda Wisnu Kencana (GWK) Cultural Park, Ungasan, Bali diresmikan oleh Presiden Republik Indonesia yaitu Bapak Ir. H. Joko Widodo setelah 28 tahun proses pembangunan.

Patung Garuda Wisnu Kencana merupakan karya pematung terkenal Bali, I Nyoman Nuarta, yang merupakan patung tembaga terbesar di dunia serta patung tertinggi ketiga di dunia.Patung ini tentu saja menjadi ikon bagi pariwisata Bali dan Indonesia.Tentunya ada alasan yang membuat patung Garuda Wisnu Kencana menjadi ikon pariwisata Bali dan Indonesia karena Patung GWK memiliki tinggi 121 meter, dengan lebar Patung 65 meter. Jika dibandingkan dengan tinggi Patung Liberty di Amerika, yang hanya 93 meter, maka Patung GWK Bali lebih tinggi 28 meter lengkap dengan latar belakang budaya dan sejarahnya.

Ketenaran dan kemenangan Bali untuk tipe destinasi pantai dibanding berbagai destinasi pantai lainnya di ASEAN tentu saja bersebrangan dengan peletakkan ikon pariwisata Indonesia yang tidak terletak di area pantai melainkan terletak di area wisata budaya dan sejarah. Meskipun ikon pariwisata tersebut mengusung budaya Bali tetapi perlu dilakukan penelitian apakah pemilihan ikon dan pemilihan lokasi peletakkan ikon ini akan memberikan dampak yang positif untuk peningkatan pariwisata di Bali ataukah tidak memberikan dampak apapun mengingat portofolio yang paling unggul di Bali adalah pantai. Peresmian patung Garuda Wisnu Kencana ini memberikan harapan yang lebih tinggi lagi bagi peningkatan wisatawan terutama wisatawan mancanegara ke Bali, mengingat sebelumnya Bali tidak memiliki ikon spesifik untuk wisatawan datang dan mengambil foto maupun swa foto seperti Menara Eiffel di Paris atau Patung Liberty di New York. 
Untuk mengetahui peranan patung Garuda Wisnu Kencana ini terhadap peningkatan pariwisata Bali perlu dilakukan penelitian mengenai jangkauan publikasi patung Garuda Wisnu Kencana apakah sudah diketahui oleh wisatawan terutama wisatawan mancanegara. Urgensi lainnya adalahsejak peresmian patung Garuda Wisnu Kencana pada tahun 2018 lalu sampai saat ini belum ada penelitian mengenai dampak yang dihasilkan dari kehadiran patung Garuda Wisnu Kencana ini.

\section{Metodologi}

\subsection{Desain Penelitian}

Jenis penelitian ini adalah Deskriptif dengan menjabarkan hasil data yang disebarkan terhadap 80 wisatawan mancanegara baik wisatawan yang sudah pernah berkunjung ke Bali maupun wisatawan yang belum pernah berkunjung ke Bali, kuesioner disebarkan melalui media daring dari bulan Oktober 2018 - Mei 2019.

\subsection{Tipe Data}

Terdapat dua jenis tipe data yang digunakan pada penelitian ini yaitu data primer yang didapatkan dari hasil penyebaran kuesioner dan data sekunder yang didapatkan dari Biro Pusat statistik, jurnal, buku, dan berbagai website resmi pemerintah provinsi Bali.

\subsection{Metode Pengumpulan Data}

1. Dokumen

Mengumpulkan berbagai sumber dokumen untuk dapat menguatkan latar belakang, tinjauan pustaka, dan metodologi penelitian melalui media daring, pemilihan berbagai pustaka yang sesuai baik melaluibuku serta jurnal.

2. Kuesioner

Penyebaran kuesioner dilakukan melalui media daring sehubungan dengan responden adalah wisatawan mancanegara baik yang sudah maupun belum pernah ke Bali dengan tujuan utama guna mengetahui apakah wisatawan mancanegara tersebut mengetahui dan mengalami perbedaaan motivasi kunjungan dengan kehadiran Patung Garuda Wisnu Kencana ini.Kuesioner diisi oleh 80 wisatawan mancanegara.

\subsection{Metode Analisis Data}

1. Manajemen data

Dari 106 respon yang masuk dari pengisian kuesioner hanya terdapat 80 kuesioner yang dapat diolah sehubungan dengan 26 responden lainnya tidak mengisi beberapa keterangan seperti benua dan negara asal responden. Pada tahapan manajemen data ini penulis membersihkan data dan hanya mengolah data yang relevan.

2. Entry data

Mengolah data sesuai dengan kebutuhan penelitian dimana data dari responden akan dibagi kedua hal yaitu sosio-demografi responden dan juga jawaban atas pengetahuan akan kehadiran Patung Garuda Wisnu Kencana.

3. Analisis statistik

Penelitian ini hanya menggunakan statistik sederhana dengan pemanfaatan Microsoft Excel yang kemudian hasilnya dijabarkan dalam penjelasan desktiptif.

4. Penarikan kesimpulan

Setelah didapatkan hasil dari data yang diperoleh maka peneliti menarik kesimpulan untuk hasil penelitian ini. 


\section{Hasil dan Pembahasan}

1. Sosio-demografi

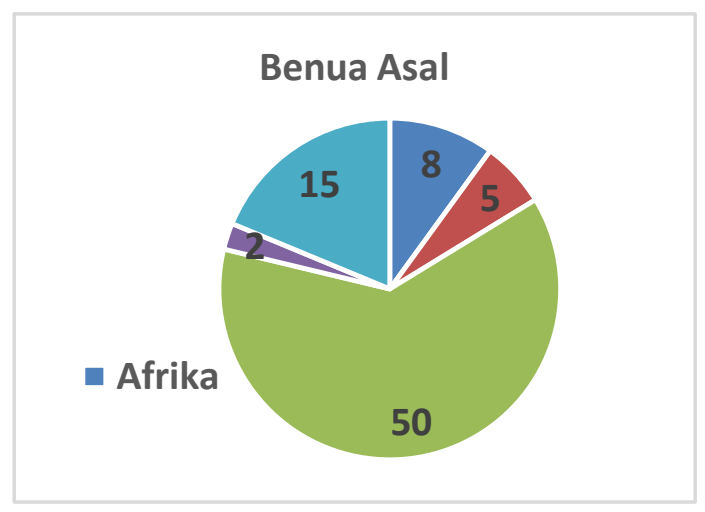

Gambar 1 Benua Asal Responden

3. Rentang usia

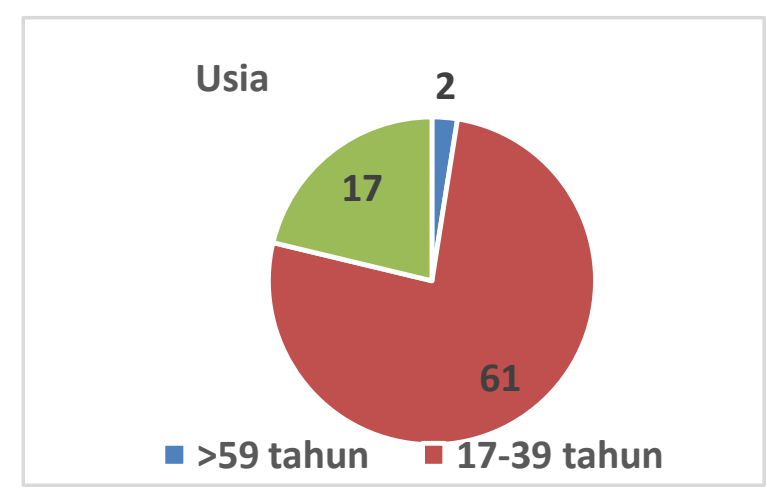

Gambar 3 Rentang Usia Responden

5. Kunjungan ke Bali

\section{Pernah berkunjung ke Bali}

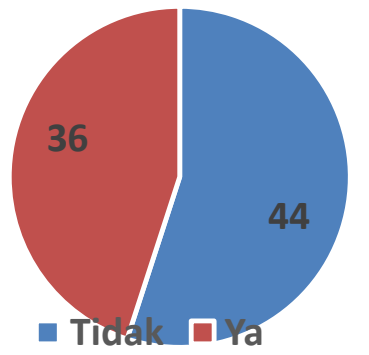

Gambar 5 Jumlah Responden yang pernah berkunjung ke Bali
2. Jenis kelamin

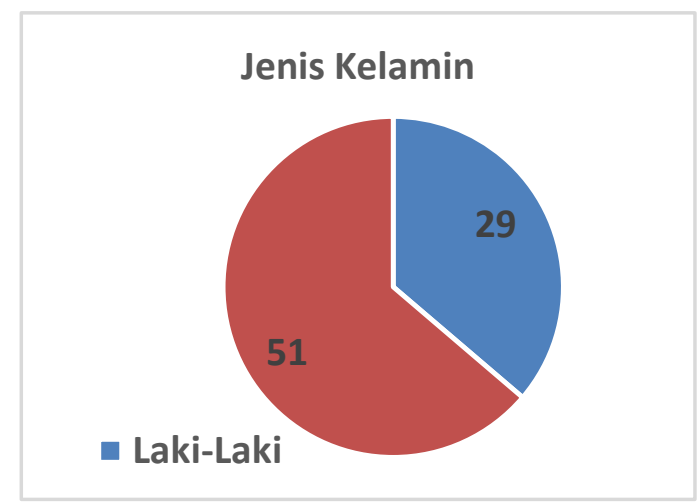

Gambar 2 Jenis Kelamin Responden

4. Responden yang pernah berkunjung ke Indonesia

Pernah berkunjung ke Indonesia

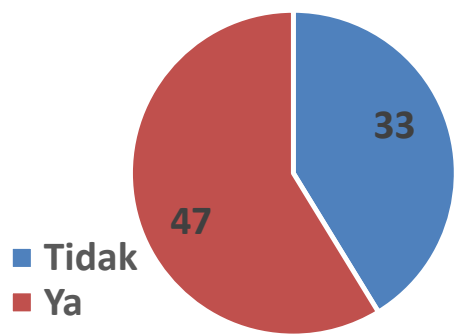

Gambar 4 Jumlah Responden yang pernah berkunjung ke Indonesia

6. Pengetahuan

- Tidak

Pengetahuan akan kehadiran

Patung Garuda Wisnu Kencana

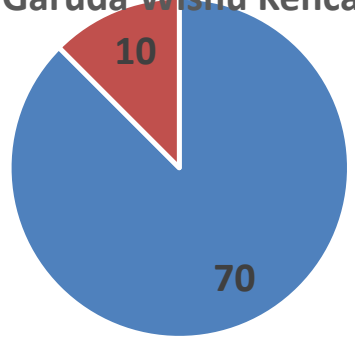

Gambar 6 Pengetahuan Responden akan kehadiran Patung Garuda Wisnu Kencana 
7. Pilihan Media Promosi

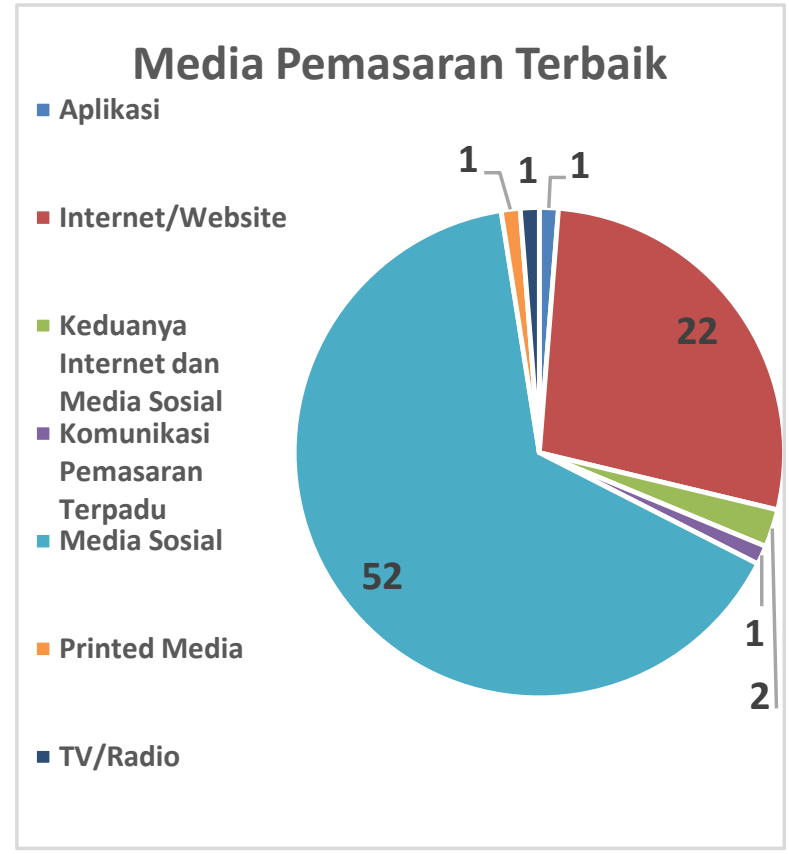

Gambar 7 Pilihan media terbaik untuk Mempromosikan Patung Garuda Wisnu Kencana

8. Negara Asal Responden

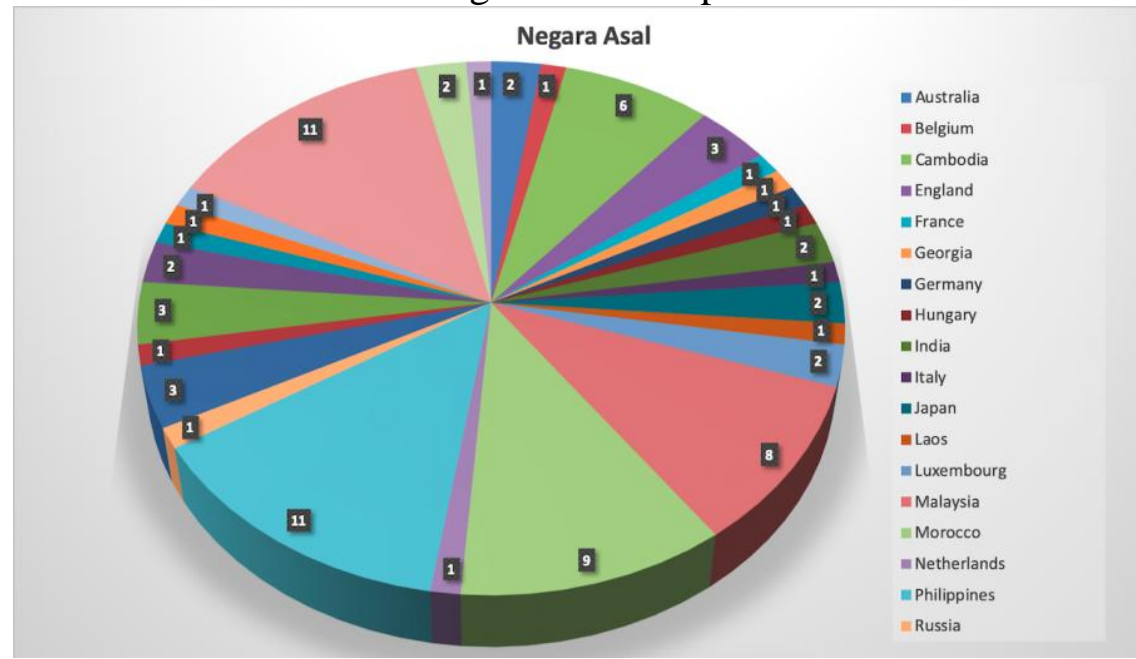

Gambar 8 Negara Asal Responden

Gambar 1 menunjukkan bahwa responden pada penelitian ini berasal dari lima benua di dunia dari enam benua dikarenakan tidak adanya responden dari benua Antartika, dan jumlah responden terbanyak berasal dari benua Asia sebanyak 50 responden, dan yang paling sedikit adalah responden yang berasal dari benua Australia. Sehubungan dengan penyebaran kuesioner penelitian dilakukan melalui media daring dengan metode simple random sampling, sehingga untuk penyebaran asal benua dan negara responden tidak menunjukkan kecenderungan tertentu akan benua/negara tersebut, tetapi dengan jumlah responden paling banyak berasal dari benua Asia menunjukkan bahwa sebaran kuesioner ini lebih banyak tersebar pada wisatawan mancanegara asal benua Asia. 
Pada gambar 8 terlihat bahwa responden pada penelitian ini berasal dari 28 negara, dengan tiga negara terbanyak yaitu: Filipina, Thailand dan Moroko dikarenakan gencarnya peneliti membagikan tautan kuesioner ke tiga negara tersebut dan wisatawan mancanegara asal ketiga negara tersebut bersedia mengisi kuesioner.

Pada gambar 2 dapat dilihat bahwa mayoritas jenis kelamin responden pada penelitian ini adalah penempuan sebanyak 51 responden, sisanya 29 responden laki-laki. Menunjukkan bahwa wisatawan mancanegara dengan jenis kelamin perempuan lebih banyak mendapatkan tautan kuesioner dan lebih bersedia mengisi kuesioner.

Pada gambar 3 terlihat bahwa rentang usia 17-39 tahun adalah rentang usia responden yang paling banyak berpartisipasi pada penelitian ini. Pembagian rentang usia ini hanya untuk mengetahui rentang usia wisatawan yang paling aktif dalam melakukan kegiatan wisata. Dimana usia<17 tahun, 40-59 tahun dan $>59$ tahun tidak melakukan kegiatan wisata sebanyak rentang usia 17-39 tahun.

Gambar 4 memperlihatkan bahwa mayoritas responden sudah pernah berkunjung ke Indonesia yaitu sebanyak 47 responden yang sudah pernah berkunjung ke Indonesia, tetapi tidak diketahui provinsi dan tujuan berkunjung ke Indonesia apakah untuk melakukan kegiatan wisata atau untuk kegiatan lainnya. Pertanyaan berkunjung ini diperlukan untuk menilai apakah seluruh wisatawan mancanegara yang pernah ke Indonesia pasti pernah berkunjung ke Bali atau tidak.

Pada Gambar 5, meskipun 47 responden sudah pernah berkunjung ke Indonesia tetapi hanya 36 diantaranya yang sudah pernah berkunjung ke Bali, sebanyak 44 responden lainnya belum pernah berkunjung ke Bali. Tetapi jumlah ini sudah cukup tinggi mengingat hanya 11 responden yang sudah pernah ke Indonesia tetapi belum berkunjung ke Bali.Hal ini menunjukkan magnet Bali sebagai destinasi wisata di Indonesia besar.

Sedangkan gambar 6 menunjukkan bahwa sebanyak 70 responden $(87,5 \%)$ belum tahu mengenai kehadiran patung Garuda Wisnu Kencana yang sudah diresmikan dan dibuka untuk umum sejak satu tahun lalu. Hal ini sangatlah disayangkan, karena patung Garuda Wisnu Kencana ini seharusnya menjadi kebanggan pariwisata Indonesia dan sebagaiikon pariwisata yang bertujuan untuk lebih meningkatkan jumlah wisatawan terutama wisatawan mancanegara untuk berkunjung ke Indonesia khususnya ke Bali. Tetapi, hasil penelitian menunjukkan bahwa mayoritas responden masih belum mengetahui adanya kehadiran patung Garuda Wisnu Kencana ini di Bali. Hal ini menunjukkan minimnya publikasi mengenai kehadiran patung Garuda Wisnu Kencana ini.

Dan pada gambar 7 menunjukkan bahwa mayoritas responden menyarankan penggunaan media sosial sebagai media terbaik untuk mempromosikan patung Garuda Wisnu Kencana yaitu sebanyak 52 responden, sisanya menyarankan melalui internet/website, aplikasi dan komunikasi pemasaran terpadu, dan yang terakhir melalui media cetak. 


\section{Kesimpulan}

Kehadiran Patung Garuda Wisnu Kencana merupakan hal yang sangat ditunggu-tunggu untuk perkembangan Pariwisata Indonesia mengingat Patung ini memakan waktu 28 tahun untuk proses pembangunan sampai dengan peresmian pada 22 September 2019 oleh Bpk Joko Widodo selaku Presiden Republik Indonesia. Patung ini juga ditetapkan sebagai ikon pariwisata Indonesia yang selama ini tidak memiliki ikon pariwisata Indonesia dan hanya memiliki ikon per Destinasi Pariwisata.

Sayangnya setelah satu tahun berlalu mayoritas responden pada penelitian ini yaitu sebanyak 87.5\% responden tetaptidak mengetahui kehadiran patung Garuda Wisnu Kencana tersebut, hanya $12,5 \%$ responden yang mengetahui kehadiran patung Garuda Wisnu Kencana ini. Apabila kehadirannya saja tidak diketahui, tentunya ikon pariwisata ini tidak memberikan dampak apapun pada perkembangan pariwisata di Bali dan Indonesia

Meskipun sebanyak 55\% responden pernah berkunjung ke Balitetapi kesadaran wisatawan mancanegara akan ikon pariwisata ini masih sangat rendah, ditunjukkan dengan sebanyak $87.5 \%$ responden belum mengetahui akan kehadiran ikon pariwisata Indonesia yang baru ini. Hal ini tentunya disebabkan oleh minimnya publikasi mengenai kehadiran ikon pariwisata baru ini.Untuk membuat wisatawan mancanegara sekedar mengetahui kehadiran akan ikon pariwisata ini tentunya membutuhkan usaha promosi yang tinggi. Dengan kesadaran akan kehadiran ikon pariwisata ini diharapkan akan meningkatkan tingkat kunjungan ke Indonesia pada umumnya dan ke Bali pada khususnya.

Kementerian Pariwisata Indonesia tentunya sudah memiliki rencana pemasaran terintegrasi yang berdasarkan Laporan Kinerja Kementerian Pariwisata Indonesia 2018 menyatakan bahwa banyak sekali upaya promosi dan pemasaran yang sudah dilakukan dan banyak juga penghargaan yang sudah didapatkan, tetapi sayangnya promosi yang dilakukan masih seputar Pesona Indonesia/Wonderful Indonesia dan belum menyentuh mengenai publikasi kehadiran Patung Garuda Wisnu Kencana. Hal ini yang mungkin menjadi penyebab minimnya pengetahuan dan kesadaran akan kehadiran patung Garuda Wisnu Kencana.

Sangat disayangkan kehadiran ikon pariwisata yang memakan waktu sangat lama untuk pembangunan dengan berbagai pro dan kontra yang ada, setelah ikon pariwisata diresmikan tetapi belum dilakukan promosi yang gencar akan ikon pariwisata ini sehingga kehadirannya belum memberikan manfaat yang signifikan baik untuk perkembangan pariwisata di Bali pada umumnya dan perkembangan pariwisata di Indonesia pada khususnya.

\section{Saran}

Diperlukan adanya penelitian lebih lanjut untuk melihat apakah dengan sosialisasi dan edukasi yang singkat mengenai kehadiran patung Garuda Wisnu Kencana ini memiliki pengaruh terhadap tingkat motivasi wisatawan mancanegara untuk berkunjung ke Bali.

Pada tahun 2019 ini juga diharapkan Kementerian Pariwisata juga melakukan promosi kehadiran ikon pariwisata Indonesia patung Garuda Wisnu Kencana bersamaan dengan branding Pesona Indonesia/Wonderful Indonesia.

\section{Ucapan Terimakasih}

Penelitian ini didanai oleh Universitas Bunda Mulia.Terimakasih kami sampaikan kepada Departemen Penelitian dan Pengabdian kepada Masyarakat Universitas Bunda Mulia atas dukungan dana yang diberikan sehingga penelitian ini bisa terlaksana. 


\section{Daftar Pustaka}

Sri Anindiati Nursastri.(2017). Bali Dinobatkan sebagai Destinasi Wisata Terbaik di Dunia. Dilihat pada tanggal $20 \quad$ September 2018 dari https://travel.kompas.com/read/2017/04/14/200540027/bali.dinobatkan. sebagai.destinasi.wisata.terb aik.di.dunia

I Ketut Sutika.(2014). Budaya masih Menjadi Daya Tarik Wisata Bali. Dilihat pada tanggal 20 September 2018 dari https://bali.antaranews.com/berita/53817/budaya-masih-jadi-daya-tarik-wisata-bali

Danu Hermansyah, Bagja Waluya. (2012). Analisis Faktor-faktor Pendorong Motivasi Wisatawan Nusantara Berkunjung ke Kebun Raya Bogor.Tourism and Hospitality Essentials (THE) Journal, Vol.II, No.1.

Dian Rizki Maulidiya Muksin, Sunarti. (2018). Pengaruh Motivasi Wisatawan terhadap Keputusan Berkunjung Wisatawan di Ekowisata Mangrove Wonorejo Surabaya. Jurnal Administrasi Bisnis (JAB). Vol. 55 No. 1.

Elizabeth Kristina Jayadi, Ni Putu Eka Mahadewi, I GPB. Sasrawan Mananda. (2017). Karakteristik dan Motivasi Wisatawan Berkunjung ke Pantai Green Bowl, Ungasan, Kuta Selatan, Bali.Jurnal Analisis Pariwisata Vol. 17 No. 2.

Komang Ratih Tunjungsari. (2018). Karakteristik dan Persepsi Wisatawan Mancanegara di kawasan Sanur dan Canggu.Jurnal Pariwisata Terapan. Vol. 2 No 2.doi: 10.22146/jpt.43178

Sugiyono.(2007). Metode Penelitian Administasi.Bandung : Alvabeta.

Suhendroyono, Rizki. (2016). Pengelolaan Wisara Alam Watu Payung sebagai ikon wisata berbasis budaya di Gunungkidul Yogyakarta. Jurnal Kepariwisataan.Sekolah Tinggi Pariwisata Ambarrukmo Yogyakarta.Vol 10 No. 1.

Uma Sekaran. (2006). Metode Penelitian Bisnis.Jakarta : Salemba Empat.

Warren, G. and Dinnie, K. (2017).Exploring the dimensions of place branding: an application of the ICON model to the branding of Toronto. International Journal of Tourism Cities.Vol. 3 No. 1. doi: 10.1108/IJTC-10-2016-0035 